\title{
Effects of tobacco smoke inhalation on the morphology and cell proliferation rate in Wistar rats submandibular glands
}

\author{
Efeitos da inalação de fumaça de tabaco sobre a morfologia e a taxa de proliferação celular em \\ glândulas submandibulares de ratos Wistar \\ Efectos de la inhalación de humo de tabaco en la morfología y la tasa de proliferación celular en \\ las glándulas submandibulares de ratas Wistar
}

Received: 06/18/2021 | Reviewed: 06/25/2021 | Accept: 06/28/2021 | Published: 07/12/2021

Lorraine Stephanie Hiss
ORCID: https://orcid.org/0000-0003-3872-287X
Federal University of Triângulo Mineiro, Brazil
E-mail: lorraine_hiss@ hotmail.com
Anna Cecília Dias Maciel Carneiro
ORCID: https://orcid.org/0000-0003-4865-1286
Federal University of Triângulo Mineiro, Brazil
E-mail: annaceciliamaciel@ gmail.com
Rodrigo César Rosa
ORCID: https://orcid.org/0000-0003-3157-0826
Federal University of Triângulo Mineiro, Brazil
E-mail: rodrigo.rosa@ uftm.edu.br
Adilha Misson Rua Micheletti
ORCID: https://orcid.org/0000-0003-2101-0366
Federal University of Triângulo Mineiro, Brazil
E-mail: adilha.micheletti@ uftm.edu.br
José Batista Volpon
ORCID: https://orcid.org/0000-0002-2120-0138
University of São Paulo, Brazil
E-mail: jbvolpon@ fmrp.usp.br
Virgínia Oliveira Crema
ORCID: https://orcid.org/0000-0001-5219-532X
Federal University of Triângulo Mineiro, Brazil
E-mail: virginia.crema@ uftm.edu.br

\begin{abstract}
Cigarette smoke compromises the salivary glands, altering saliva. Cotinine is the most effective biomarker to assess tobacco consumption, and passive smokers are characterized by serum cotinine levels above $2.1 \mathrm{ng} / \mathrm{mL}$. This study aimed to evaluate the effect of exposure to cigarette smoke on rats submandibular glands. The morphology, the proliferative cells of intercalated ducts (immunohistochemistry for KI-67) and its correlation with serum cotinine levels were analyzed. Wistar rats were grouped: control (C); inhalation of smoke for 30 days (T1) and 60 days (T2). Data were analyzed with the Levene variance homogeneity test, Spearman's test, ANOVA and Tukey's post-test, with significance $\mathrm{p}<0.05$. Morphology showed a preserved parenchyma in C, and altered secretory cells in $\mathrm{T} 1$ and T2. There was a significant reduction in the number of proliferative cells [ANOVA, $F=4.726 ;$ d.f. $=2,26 ; \mathrm{p}<0.05$ ]: $\mathrm{C}$ vsT1 $(\mathrm{p}<0.05)$ and $\mathrm{C}$ vs T2 $(\mathrm{p}<0.05)$. T1 and T2 serum cotinine levels were significantly higher $(\mathrm{p}<0.05)$ than $\mathrm{C}$. There was a significant negative correlation $[\rho=-0.418, n=27, p<0.05]$ between serum cotinine levels and the rate of cellular proliferation. These results suggest that of tobacco smoke inhalation has a decreased of the cellular proliferation rate and altered morphology in submandibular glands de ratos Wistar.
\end{abstract}

Keywords: Cell proliferation; Cigarrete; KI-67; Passive smoker; Salivary glands; Submandibular gland.

\section{Resumo}

Cigarette smoke compromises the salivary glands, altering saliva. Cotinine is the most effective biomarker to assess tobacco consumption, and passive smokers are characterized by serum cotinine levels above $2.1 \mathrm{ng} / \mathrm{mL}$. O objetivo deste estudo foi avaliar o efeito da exposição à fumaça do cigarro nas glândulas submandibulares de ratos. Foram analisadas a morfologia, as células proliferativas dos ductos intercalados (imunohistoquímica para KI-67) e sua correlação com os níveis séricos de cotinina. Ratos Wistar foram agrupados: controle (C); inalação de fumaça por 30 dias (T1) e 60 dias (T2). Os dados foram analisados com os testes de homogeneidade de variância de Levene, teste de Spearman, ANOVA e pós-teste de Tukey, com significância $\mathrm{p}<0,05$. A morfologia mostrou parênquima 
preservado em $\mathrm{C}$ e células secretoras alteradas em T1 e T2. Houve uma redução significativa no número de células proliferativas [ANOVA, F=4,726; d.f. = 2,26; p <0,05]: C vs T1 (p<0,05) e C vs T2 (p <0,05). Os níveis séricos de cotinina T1 e T2 foram significativamente maiores $(\mathrm{p}<0,05)$ do que $\mathrm{C}$. Houve uma correlação negativa significativa $[\rho=-0,418, n=27, p<0,05]$ entre os níveis séricos de cotinina e a taxa de proliferação celular. Esses resultados sugerem que a inalação de fumaça de tabaco leva a diminuição da taxa de proliferação celular e morfologia alterada nas glândulas submandibulares de ratos Wistar.

Palavras-chave: Proliferação celular; Cigarro; KI-67; Fumante passivo; Glândulas salivares; Glândula submandibular.

\section{Resumen}

El humo del cigarrillo compromete las glándulas salivales alterando la saliva. La cotinina es el biomarcador más eficaz para evaluar el consumo de tabaco y los fumadores pasivos se caracterizan por niveles de cotinina sérica superiores a 2,1 ng / ml. Este estudio tuvo como objetivo evaluar el efecto de la exposición al humo del cigarrillo en las glándulas submandibulares de ratas. Se analizó la morfología, las células proliferativas de los conductos intercalados (inmunohistoquímica para KI-67) y su correlación con los niveles séricos de cotinina. Las ratas Wistar se agruparon: control (C); inhalación de humo durante 30 días (T1) y 60 días (T2). Los datos fueron analizados con la prueba de homogeneidad de varianza de Levene, prueba de Spearman, ANOVA y postest de Tukey, con significancia $\mathrm{p}<0.05$. La morfología mostró un parénquima conservado en $\mathrm{C}$ y células secretoras alteradas en T1 y T2. Hubo una reducción significativa en el número de células proliferativas [ANOVA, $F=4.726 ;$ d.f. $=2$,26; $p$ $<0,05]$ : C vs T1 (p <0,05) y C vs T2 (p <0,05). Los niveles de cotinina sérica de T1 y T2 fueron significativamente más altos $(\mathrm{p}<0,05)$ que $\mathrm{C}$. Hubo una correlación negativa significativa $[\rho=-0,418, \mathrm{n}=27, \mathrm{p}<0,05]$ entre los niveles de cotinina sérica y la tasa de proliferación celular. Estos resultados sugieren que Efectos de la inhalación de humo de tabaco tiene una disminución de la tasa de proliferación celular y una morfología alterada en las glándulas submandibulares de las ratas Wistar.

Palabras clave: Proliferación celular; Cigarrillo; KI-67; Fumador pasivo; Glándulas salivales; Glándula submandibular.

\section{Introduction}

Several studies report the negative impact of smoking on the oral health, cigarette smoke has identified about 5,000 substances and many of them have toxic, mutagenic and carcinogenic effects (Leão et al., 2015). Cigarette smoke inhalation promote morphological changes in the salivary glands, such as hyperemia, vasodilation and vacuolar degeneration, and the proteins and salivary enzymes, such as amylase, have reduced activity in smokers (Fujinami et al., 2009). It is also associated with the arising and exasperation of periodontal disease (Tomar \& Asma, 2000) and the occurrence of caries (Axelsson et al., 1998).

The cotinine, nicotine metabolite, is used to evaluate cigarette exposure, being a marker is highly sensitive and specific and can be dosed in active and passive smokers (Leão et al., 2015). Cotinine serum levels up to $2.0 \mathrm{ng} / \mathrm{mL}$ characterize non-exposed individuals and values greater than $2.1 \mathrm{ng} / \mathrm{mL}$ characterize a passive smoker from 17.6 characterized by a smoker (Chiu et al., 2008; Malafatti \& Martins, 2009).

Passive smokers can absorb up to one-sixth of the amount of smoke absorbed by the active smoker (Chen \& Petitti, 1995), they have a higher risk of developing lung cancer, heart and respiratory diseases (Stark et al., 2007), dental problems, decreased salivary $\mathrm{pH}$, changes in salivary flow rate, buffer capacity, and protein levels (Ferragut et al., 2011).

This study aimed to evaluate the effect of inhalation of cigarette smoke on the rats submandibular glands by histological and morphometric evaluation of the proliferation rate of the cells of the intercalated ducts. These cells are responsible for cell renewal of the glandular parenchyma (Schwartz-Arad et al., 1988).

\section{Methodology}

This is a prospective, experimental, quantitative and analytical study (Pereira et al, 2018). This research was approved by the Ethics Committee on Animal Use Medicine School of the University of São Paulo (139/2013). 27 female 
Wistar rats with eight weeks were randomly subdivided in the control group $(C, n=10)$; animals that inhaled cigarette smoke for 30 days (T1, $\mathrm{n}=10)$ and for 60 days $(\mathrm{T} 2, \mathrm{n}=7)$.

The device used for exposure to cigarette smoke, through a previously described model (Santiago et al., 2017). During the first 5 days, the animals were exposed to smoke inhalation of four cigarettes, containing 0.8 mg of nicotine, 10 $\mathrm{mg}$ of tar and $10 \mathrm{mg}$ of carbon monoxide each, by alternating injections of fresh air for $30 \mathrm{sec}$ and smoke air for $15 \mathrm{sec}$.

After that, they were exposed twice a day to smoke four cigarettes in the morning and four cigarettes in the afternoon for the remainder of the trial, totaling eight cigarettes a day. The control group received only "puffs" of ambient air for the same period of time of treated group.

The status of passive smoker was confirmed by gas chromatography in blood samples (Chiu et al., 2008; Malafatti \& Martins, 2009): non-smokers up to $2.0 \mathrm{ng} / \mathrm{mL}$ and passive smokers higher than $2.1 \mathrm{ng} / \mathrm{mL}$.

After the experimental period, the animals were anesthetized with Thiopental Sodium $60 \mathrm{mg} / \mathrm{kg}$ intraperitoneally and euthanized by decapitation. The submandibular glands were dissected and fixed in phosphate buffer, $\mathrm{pH} 7.4 / 10 \%$ formaldehyde for $48 \mathrm{~h}$. Samples were dehydrated, diaphanized and embedded in paraffin. Histological sections of $4 \mu \mathrm{m}$ were placed on pre-coated slides with Poly-y-lysine ${ }^{\circledR}$. Histological sections were stained with Hematoxylin and Eosin by conventional methods. Qualitative morphological analysis was performed throughout the histological sections.

For immunohistochemical reaction for KI-67, after dewaxing and hydration of the sections, antigens were recovered with tris/EDTA buffer solution, pH 9.0 in a Decloaking Chamber, at $110^{\circ} \mathrm{C}$ for $15 \mathrm{~min}$. The sections were incubated with: endogenous peroxidase solution with $\mathrm{H}_{2} \mathrm{O}_{2}$ and protein blocking solution; anti-KI-67 primary antibody (MIB-1, sc-101861, Santa Cruz Biotechnology, Inc., Santa Cruz, CA, USA) 1:50 PBS/0.2\% Triton, overnight at room temperature. REVEAL biotin-free detection system and DAB substrate system (BIOGEN ${ }^{\circledR}$, Pleasanton, CA), according to the manufacturer's instructions. The histological sections were counter-stained with Hematoxylin for $30 \mathrm{sec}$. Negative controls consisted of the omission of the primary antibody and positive controls were performed on sections of palatine tonsils. The KI-67 positive nuclei of the intercalated duct cells were quantified in ten random fields, using a 100x objective.

For statistical analysis, the results were analyzed with the SPSS $20.0^{\circledR}$ program and the graphs were done with the program Graphpad Prism ${ }^{\circledR}$. Data were analyzed with the Levene variance homogeneity test, Spearman's test, ANOVA and Tukey's post-test, with significance $\mathrm{p}<0.05$.

\section{Results}

In group $\mathrm{C}$, the secretory cells (cells responsible for saliva production) were seen with pyramidal morphology, basophilic cytoplasm, spherical nuclei, basal, with similar size, some presented loose chromatin and evident nucleolus (Figure 1A-B). In the T1 group (30 days inhalation), the secretory cells presented weakly stained cytoplasm and nuclei with dense chromatin (Figure 1C-D). In group T2 (60 days inhalation), cells with pyramidal and other completely unformed shapes, reduced cytoplasm and some pycnotic nuclei were visualized (Figure 1E-F). In all groups studied, the stroma and duct system were preserved.

After exposure to cigarette smoke, the proliferation rate of intercalated duct cells (biological process that guarantees the renewal of secretory cells) was significantly different (ANOVA, F = 4.726, d.f. = 2,26; p<0.05). The number of proliferative cells in T1 $(0.16 \pm 0.06$ cells $)$ and in T2 $(0.14 \pm 0.07$ cells $)$ decreased significantly $(\mathrm{p}<0.05)$, compared to C $(0.27 \pm 0.12$ cells). However, there was no statistical difference $(\mathrm{p}>0.05)$ in the proliferation rate between groups $\mathrm{T} 1$ and $\mathrm{T} 2$ (Figure 2A). 
Research, Society and Development, v. 10, n. 8, e28510817327, 2021

(CC BY 4.0) | ISSN 2525-3409 | DOI: http://dx.doi.org/10.33448/rsd-v10i8.17327

Figure 1. Effect of exposure to inhalation of cigarette smoke on morphology of the submandibular gland. Hematoxilin and Eosin staining. Control group (A and B) and animals that inhaled cigarette smoke for 30 (C and D) and 60 days (E and F). (cs) secretory cells and (di) intercalated duct cells.
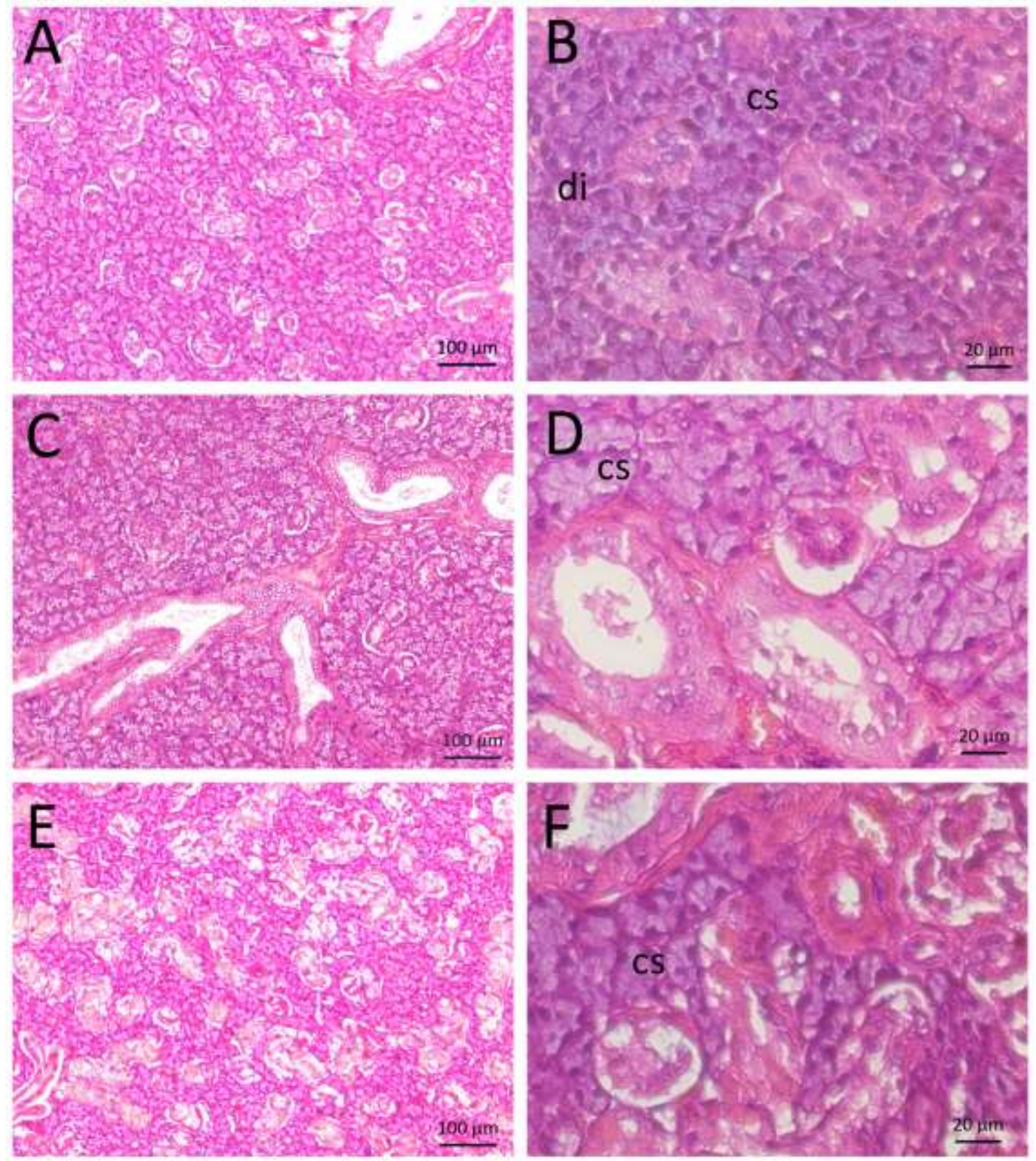

Fonte: Autores. 
Figure 2. Effect of exposure to inhalation of cigarette smoke on the proliferation rate of intercalated duct cells of the submandibular gland (A). Control group (C) and animals that inhaled cigarette smoke for 30 days (T1) and for 60 days (T2). ANOVA, p<0.05. (B) Correlation between the serum levels of cotinine and the proliferation rate of the cells of the submandibular gland intercalated ducts. Spearman's test, $\mathrm{p}<0.05$.
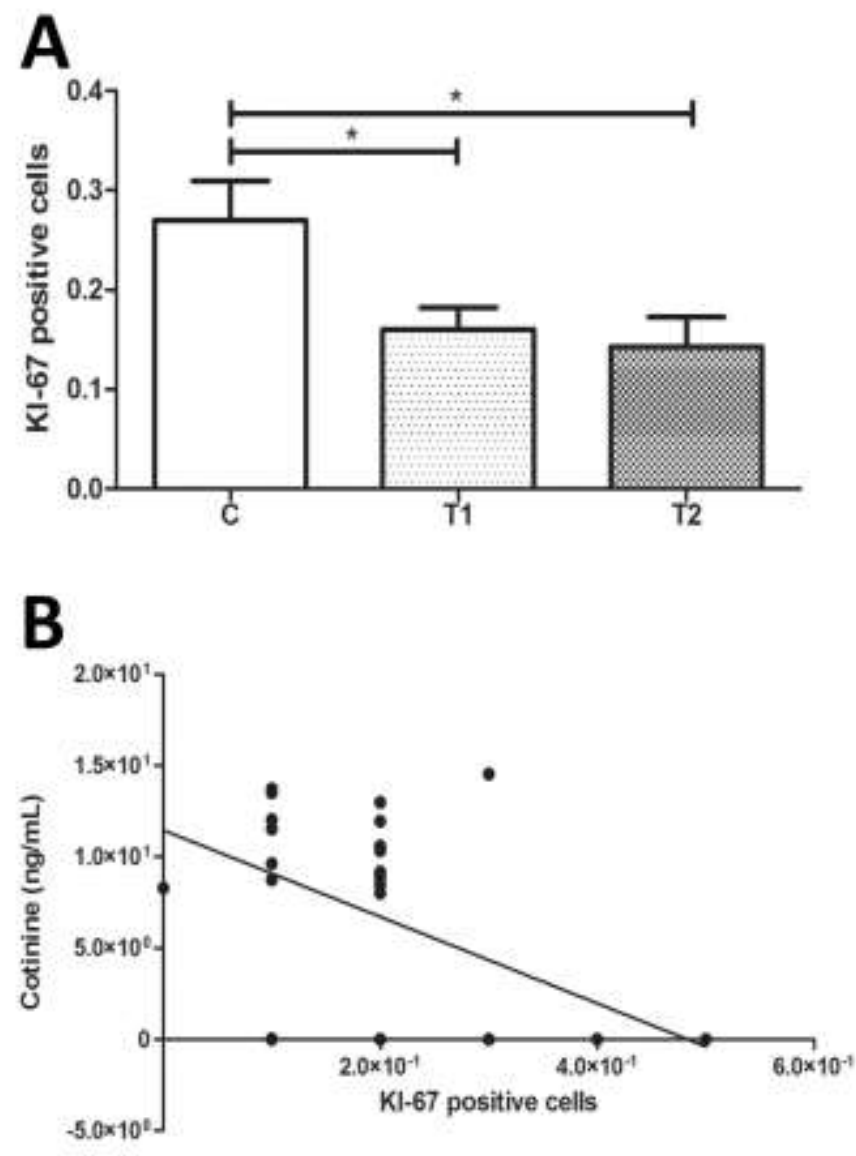

Fonte: Autores.

Serum cotinine (metabolite of nicotine from tobacco) levels in T1 and T2 were characteristic of passive smoker (Table 1), and were significantly higher then control $[F(2,26)=670,585, p<0,0001]$. Interestingly, there was a statistically significant negative correlation $[\rho=-0.418, n=27, \mathrm{p}<0.05]$ between the serum levels of cotinine and the proliferation rate of the cells of the submandibular gland intercalated ducts. Therefore, the higher the number of KI-67 positive cells, the lower the serum levels of cotinine (Figure 2B).

Table 1. Status of passive smoker by cotinine serum level of the animals.

\begin{tabular}{c|c}
\hline Groups & Cotinine $(\mathrm{ng} / \mathrm{mL})$ \\
\hline C & $0.00 \pm 0.0$ \\
T1 & $9.09 \pm 0.8^{\mathrm{a}}$ \\
T2 & $12.8 \pm 1.1^{\mathrm{b}, \mathrm{c}}$ \\
\hline
\end{tabular}

ANOVA and Tukey's post-test. ${ }^{\mathrm{a}} \mathrm{C} v s \mathrm{~T} 1, \mathrm{p}<0.0001$; ${ }^{\mathrm{b}} \mathrm{C} v s \mathrm{~T} 2$, $\mathrm{p}<0.0001 ;{ }^{\mathrm{c}} \mathrm{T} 1$ vs $\mathrm{T} 2, \mathrm{p}<0.0001$. Soure: Authors. 


\section{Discussion}

This study demonstrated that exposure to cigarette smoke affects the morphology and proliferation rate of the intercalated duct cells in submandibular glands. In this study the inhalation of cigarette smoke promoted morphological changes in the submandibular glands and reduced the rate of cell proliferation. In agreement with these results, in a study with rats, the ligation of the duct of the submandibular gland caused the death of the acinar cells and the reduction of the proliferation of the ductal cells (Takahashi et al., 2000). Nicotine has a rapid absorption into the skin and oral and nasal mucosa due to its ability to solubilize lipids (Bao et al., 2005). Cigarette smoke can cause pre-cancerous and cancerous lesions in the oral cavity (Porter et al., 2018), even when exposure is passive, reactive oxygen species form due to accumulation of nicotine and heavy metals in the cells, which causes irreversible DNA damage (Ferragut et al., 2011). This study showed that exposure to cigarette smoke may lead to nuclear atypia of the submandibular glands, therefore, DNA damages to intercalated duct cells upon passive smoking exposure should be assessed.

In the present study, animals exposed to the inhalation of cigarette smoke presented important morphological alterations in the submandibular glands, secretory cells dysformes, reduced cytoplasm, cellular and nuclear atypia, as well as pycnotic nuclei and mitotic figures. These results are in agreement with a morphological study to evaluate the epithelialstromal interactions in the submandibular and parotid glands of rats exposed to passive smoking (Ferragut et al., 2011). Previously, vasodilation and hyperemia, cells with vacuolar degeneration in the submandibular rats, and changes in the saliva of these animals, were also described after exposure to cigarette smoke for 15 and 30 days (Fujinami et al., 2009).

Histological analysis of fragments of human parotids obtained in paroidectomy procedures were cultured and treated with nicotine for 7 days, and the results demonstrated DNA damage, acinar cell atrophy and cytoplasmic changes after the third day of exposure to nicotine (Ginzkey et al., 2010). After 60 days of exposition to cigarret smoke, the mucosa of the tongue, pharynx and larynx of Wistar rats led to increased epithelial proliferation (de Oliveira Semenzati et al., 2012). On the other hand, in this study, the rate of cell proliferation decreased in the submandibular glands after exposure to cigarette smoke for 30 and 60 days. Toxic agents and substances that promote lethal oxidative stress are not neutralized in the submandibular, causing them to be greatly impaired when exposed to cigarette smoke (Hershkovich et al., 2004).

The cells of the intercalary duct contribute to the tissue renewal of the parenchyma cells (Man et al., 2001), the cells of the intercalary duct have a high proliferative rate (Schwartz-Arad et al., 1988). KI-67, the cell proliferation marker used in this study, marks the dividing cells in the active phases of the cell cycle that express this antigen in their nuclei (Isolan et al., 2005). This immunohistochemical marker is widely used for the prognosis of carcinoma of the salivary glands (Cheuk $\&$ Chan, 2007) and, it is likely that the increase in proliferative rate is closely linked to the molecular changes preceding cancer (Feith et al., 2004; Porschen et al., 1991). In this study, control animals showed greater tissue turnover rate compared to the treated groups, demonstrating a relationship between cell proliferation and toxicity of cigarette smoke.

The effect of exposure of saliva to human cigarette smoke has been demonstrated, especially in the inactivation of the enzymes amylase, lactate dehydrogenase and acid phosphatase, besides affecting protective salivary enzymes such as peroxidase. Therefore altering the protective capacity of saliva by triggering important changes in the saliva. Its antioxidant potential and compromises oral cavity homeostasis (Nagler et al., 2000).

Nicotine is one of the 4000 components of the cigarette and is considered the most relevant because it is highly toxic and if it is distributed rapidly by the tissues of the whole body (Haufroid \& Lison, 1998). Of the total nicotine absorbed approximately $70 \%$ is biotransformed through the action of the hepatic enzyme CYP4502A6 in cotinine (Hukkanen et al., 2005), which is the major metabolite of nicotine, being a highly sensitive biomarker to assess the degree of exposure to smoke of cigarettes in active and passive smokers (Leão et al., 2015). While nicotine has a plasma half-life of 1 to 2 hours, cotinine has a plasma half-life of approximately 20 to 40 hours, so cotinine is the best choice for the quantitative analysis of 
nicotine exposure. (Hukkanen et al., 2005). This study considered serum levels greater than $2.1 \mathrm{ng} / \mathrm{mL}$ of cotinine as passive smoker status for 30 and 60 days, according to the literature (Chiu et al., 2008; Malafatti \& Martins, 2009).

In vascular smooth muscle cell culture, cotinine at lower doses had a stimulatory effect on mitoses, while higher doses had cytotoxic effects (Jacob et al., 2009). In this study, a negative correlation was seen between serum cotinine levels and the rate of cell proliferation of the intercalated ducts of submandibular glands. Differing from the model with A549 cells from human lung adenocarcinoma and T24 cells from human urinary bladder carcinoma, in which the MTT assay demonstrated that cotinine enhances the survival and proliferation of A549 and T24 cells, thus contributing to tumor development (Nowak et al., 2015). And in lymphocytes of 77 smokers, exposure to nicotine and cotinine may lead to reduced cell replication caused by DNA damage and/or decreased repair mechanisms, and this may induce cell death (CalderónEzquerro et al., 2007).

\section{Conclusion}

Although this study was carried out with Wistar rats, the obtained results suggest that of tobacco smoke inhalation leads to morphological changes and reduced proliferation rate of cells of intercalated ducts of the submandibular gland. Since the serum cotinine levels observed were from passive smoker, the correlation between the serum levels of cotinine and the proliferation rate of the submandibular gland reinforce the dangerous secondhand smoke for individuals. Future studies could elucidate possible genetic damage and the salivary flow in human smokers.

\section{Acknowledgments}

We are grateful for financial support of Fundação de Amparo à Pesquisa do Estado de Minas Gerais - FAPEMIG [Scholarship].

\section{References}

Axelsson, P., Paulander, J., \& Lindhe, J. (1998). Relationship between smoking and dental status in 35-, 50-, 65-, and 75-year-old individuals. J Clin Periodontol, 25(4), 297-305.

Bao, Z., He, X. Y., Ding, X., Prabhu, S., \& Hong, J. Y. (2005). Metabolism of nicotine and cotinine by human cytochrome P450 2A13. Drug Metab Dispos, 33(2), 258-261. https://doi.org/10.1124/dmd.104.002105

Calderón-Ezquerro, C., Sánchez-Reyes, A., Sansores, R. H., Villalobos-Pietrini, R., Amador-Muñoz, O., Guerrero-Guerra, C., Calderón-Segura, M. E., Uribe-Hernández, R., \& Gómez-Arroyo, S. (2007). Cell proliferation kinetics and genotoxicity in lymphocytes of smokers living in Mexico City. Hum Exp Toxicol, 26(9), 715-722. https://doi.org/10.1177/0960327107083451

Chen, L. H., \& Petitti, D. B. (1995). Case-control study of passive smoking and the risk of small-for-gestational-age at term. Am J Epidemiol, 142(2), 158165 .

Cheuk, W., \& Chan, J. K. (2007). Advances in salivary gland pathology. Histopathology, 51(1), 1-20. https://doi.org/10.1111/j.1365-2559.2007.02719.x

Chiu, H. T., Isaac Wu, H. D., \& Kuo, H. W. (2008). The relationship between self-reported tobacco exposure and cotinines in urine and blood for pregnant women. Sci Total Environ, 406(1-2), 331-336. https://doi.org/10.1016/j.scitotenv.2008.07.005

de Oliveira Semenzati, G., de Souza Salgado, B., Rocha, N. S., Michelin Matheus, S. M., de Carvalho, L. R., \& Garcia Martins, R. H. (2012). Histological and immunohistochemical study of the expression of p53 and ki-67 proteins in the mucosa of the tongue, pharynx and larynx of rats exposed to cigarette smoke. Inhal Toxicol, 24(11), 723-731. https://doi.org/10.3109/08958378.2012.715317

Feith, M., Stein, H. J., Mueller, J., \& Siewert, J. R. (2004). Malignant degeneration of Barrett's esophagus: the role of the Ki-67 proliferation fraction, expression of E-cadherin and p53. Dis Esophagus, 17(4), 322-327. https://doi.org/10.1111/j.1442-2050.2004.00434.x

Ferragut, J. M., da Cunha, M. R., Carvalho, C. A., Isayama, R. N., \& Caldeira, E. J. (2011). Epithelial-stromal interactions in salivary glands of rats exposed to chronic passive smoking. Arch Oral Biol, 56(6), 580-587. https://doi.org/10.1016/j.archoralbio.2010.11.017

Fujinami, Y., Fukui, T., Nakano, K., Ara, T., Fujigaki, Y., Imamura, Y., Hattori, T., Yanagisawa, S., Kawakami, T., \& Wang, P. L. (2009). The effects of cigarette exposure on rat salivary proteins and salivary glands. Oral Dis, 15(7), 466-471. https://doi.org/10.1111/j.1601-0825.2009.01572.x 
Ginzkey, C., Friehs, G., Koehler, C., Hackenberg, S., Voelker, H. U., Richter, E., \& Kleinsasser, N. H. (2010). Nicotine and methyl methane sulfonate in mini organ cultures of human parotid gland tissue. Toxicol Lett, 197(2), 69-74. https://doi.org/10.1016/j.toxlet.2010.04.032

Haufroid, V., \& Lison, D. (1998). Urinary cotinine as a tobacco-smoke exposure index: a minireview. Int Arch Occup Environ Health, 71(3), $162-168$.

Hershkovich, O., Oliva, J., \& Nagler, R. M. (2004). Lethal synergistic effect of cigarette smoke and saliva in an in vitro model: does saliva have a role in the development of oral cancer? Eur J Cancer, 40(11), 1760-1767. https://doi.org/10.1016/j.ejca.2004.03.027

Hukkanen, J., Jacob, P., \& Benowitz, N. L. (2005). Metabolism and disposition kinetics of nicotine. Pharmacol Rev, 57(1), 79-115. https://doi.org/10.1124/pr.57.1.3

Isolan, G. R., Ribas Filho, J. M., Isolan, P. M., Giovanini, A., Malafaia, O., Dini, L. I., Kummer, A., \& Negrão, A. W. (2005). [Astrocytic neoplasms and correlation with mutate p53 and Ki-67 proteins]. Arq Neuropsiquiatr, 63(4), 997-1004. https://doi.org//S0004-282X2005000600017

Jacob, T., Clouden, N., Hingorani, A., \& Ascher, E. (2009). The effect of cotinine on telomerase activity in human vascular smooth muscle cells. $J$ Cardiovasc Surg (Torino), 50(3), 345-349.

Leão, H. Z., Zettle, C. G., Cambruzzi, E., Lammers, M., Soster, P. R. d. L., Mello, F. B. d., Goulart, G. R., Campos, D. d., \& Jotz, G. P. (2015). The Effects of Passive Smoking on Laryngeal and Tracheal Mucosa in Male Wistar Rats During Growth: An Experimental Study. J Voice, 31(1):126.e19-126.e24.

Malafatti, L., \& Martins, I. s. (2009). Aspectos analíticos da derterminação de continina em matrizes biológicas. Revista Brasileira de Toxicologia, 22, 9-20.

Man, Y. G., Ball, W. D., Marchetti, L., \& Hand, A. R. (2001). Contributions of intercalated duct cells to the normal parenchyma of submandibular glands of adult rats. Anat $\operatorname{Rec}, 263(2), 202-214$.

Nagler, R., Lischinsky, S., Diamond, E., Drigues, N., Klein, I., \& Reznick, A. Z. (2000). Effect of cigarette smoke on salivary proteins and enzyme activities. Arch Biochem Biophys, 379(2), 229-236. https://doi.org/10.1006/abbi.2000.1877

Nowak, J. M., Klimaszewska-Wiśniewska, A., Izdebska, M., Gagat, M., \& Grzanka, A. (2015). Gelsolin is a potential cellular target for cotinine to regulate the migration and apoptosis of A549 and T24 cancer cells. Tissue Cell, 47(1), 105-114. https://doi.org/10.1016/j.tice.2014.12.003

Pereira, A. S. et al. (2018). Metodologia da pesquisa cientifica. UFSM. https://repositorio.ufsm.br/bitstream/handle/1/15824/Lic_Computacao_MetodologiaPesquisa-Cientifica.pdf?sequence $=1$.

Porschen, R., Kriegel, A., Langen, C., Classen, S., Hilse, M., Lohe, B., Hengels, K. J., \& Borchard, F. (1991). Assessment of proliferative activity in carcinomas of the human alimentary tract by Ki-67 immunostaining. Int J Cancer, 47(5), 686-691.

Porter, S., Gueiros, L. A., Leão, J. C., \& Fedele, S. (2018). Risk factors and etiopathogenesis of potentially premalignant oral epithelial lesions. Oral Surg Oral Med Oral Pathol Oral Radiol, 125(6), 603-611. https://doi.org/10.1016/j.oooo.2018.03.008

Santiago, H. A., Zamarioli, A., Sousa Neto, M. D., \& Volpon, J. B. (2017). Exposure to Secondhand Smoke Impairs Fracture Healing in Rats. Clin Orthop Relat Res, 475(3), 894-902. https://doi.org/10.1007/s11999-016-5184-6

Schwartz-Arad, D., Arber, L., Arber, N., Zajicek, G., \& Michaeli, Y. (1988). The rat parotid gland--a renewing cell population. J Anat, 161, 143-151.

Stark, M. J., Rohde, K., Maher, J. E., Pizacani, B. A., Dent, C. W., Bard, R., Carmella, S. G., Benoit, A. R., Thomson, N. M., \& Hecht, S. S. (2007). The impact of clean indoor air exemptions and preemption policies on the prevalence of a tobacco-specific lung carcinogen among nonsmoking bar and restaurant workers. Am J Public Health, 97(8), 1457-1463. https://doi.org/10.2105/AJPH.2006.094086

Takahashi, S., Nakamura, S., Suzuki, R., Islam, N., Domon, T., Yamamoto, T., \& Wakita, M. (2000). Apoptosis and mitosis of parenchymal cells in the duct-ligated rat submandibular gland. Tissue Cell, 32(6), 457-463.

Tomar, S. L., \& Asma, S. (2000). Smoking-attributable periodontitis in the United States: findings from NHANES III. National Health and Nutrition Examination Survey. J Periodontol, 71(5), 743-751. https://doi.org/10.1902/jop.2000.71.5.743. 